International Journal of Instruction e-ISSN: 1308-1470 • www.e-iji.net

Article submission code: 20201014012857

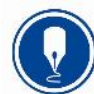

October $2021 \bullet$ Vol.14, No.4

p-ISSN: 1694-609X

pp. 913-932

Received: 14/10/2020

Revision: 06/05/2021
Accepted: 30/05/2021

OnlineFirst: 10/09/2021

\title{
Exploring the Impact of Blogging in English Classrooms: Focus on the Ideal Writing Self of EFL Learners
}

\section{Sam Yousefifard}

Corresponding author, Instructional Technology Designer, University of British Columbia, Vancouver, Canada, sam.yousefifard@ubc.ca

\section{Jalil Fathi}

Asst. Prof., TEFL, University of Kurdistan, Sanandaj, Iran, jfathi13@yahoo.com

\begin{abstract}
In order to contribute to the line of inquiry on the use of Web 2.0 technology in Second Language (L2) learning, the current research employed a quantitative research method to probe the contribution of blog-mediated writing instruction to developing the writing skill and the ideal writing self of Iranian English-as-aForeign Language (EFL) learners. In so doing, a sample of 47 Iranian EFL learners in a private language institute were recruited as the subjects of this research. These students were then divided into two classes and were randomly assigned to an experimental class $(\mathrm{N}=24)$ and a control class $(\mathrm{N}=23)$. Concerning the research intervention, the students of the blog group used blogs in their writing instruction while those in the control group received the conventional, inside-the-class writing instruction. The Ideal L2 Writing Self Scale was given before and after the intervention as the pre-test and the post-test, respectively. The results from ANCOVA analysis indicated that although both groups progressed in both writing performance and ideal writing self scores, the learners of the blog group outperformed those of control group, suggesting that the blog-mediated instruction significantly contributed to improving the writing performance $(F=9.78, p=$ 0.003 , partial eta squared $=0.18)$ and ideal L2 writing self of the EFL students $(F=$ $11.678, p=0.001$, partial eta squared $=0.210$ ). These results may offer important implications for EFL writing research and pedagogy. Overall, the integration of blogs in L2 pedagogy might be effective type of blended learning approach which can result in better linguistic and affective outcomes.
\end{abstract}

Keywords: web 2.0, EFL writing, blogs, L2 motivational self-system, ideal self

\section{INTRODUCTION}

With no doubt, motivation can significantly affect L2 learning outcomes (Dörnyei \& Ushioda, 2009; Gardner; 1985; 2001; Gardner \& MacIntyre, 1993; Kim \& Kim, 2020; Yang, 2011; Zhang, Dai, \& Ardasheva, 2020). Having proposed a new theory of L2 motivation, Dörnyei $(2005,2009)$ introduced the L2 motivational self system, which is

Citation: Yousefifard, S., \& Fathi, J. (2021). Exploring the impact of blogging in English classrooms: Focus on the ideal writing self of EFL learners. International Journal of Instruction, 14(4), 913-932. https://doi.org/10.29333/iji.2021.14452a 
grounded in the theory of possible selves (Henry, 2020; Markus \& Nurius,1986; Nourzadeh, Fathi, \& Davari, 2020) and the theory of self-discrepancy (Higgins, 1987). This reconceptualization of motivation theory constitutes three underlying elements including ideal L2 self, ought-to L2 self, and an L2 learning experience. The ideal L2 self is concerned with the aspired image of an individual' ideal self, denoting the desire to use L2 fluently. In other words, it refers to the extent to which the L2 learners can imagine themselves as the proficient user of English in the future. This ideal image emanates from the integrative and internalized incentives for language learning. The ought-to L2 self refers to a representation of a future self which is created by the expectations of valued others. This self is an individual's characterization of the qualities that others believes you should or ought to possess. From this perspective, L2 learner is motivated to learn language in order to satisfy the expectations of significant others and not to disappoint them through avoiding potential unfavorable L2 learning outcomes. Both ideal and ought selves serve as strong motivational drives for language learning because of the willingness to alleviate the difference between individuals' actual self and their ideal or ought selves (Dörnyei, 2009). As the third element of the model, the L2 learning experience refers to "situated, 'executive' motives related to the immediate learning environment and experiences" (Dörnyei, 2009, p. 29). Learning experience is mainly related to perceptions toward L2 learning. The ideal and ought-to L2 selves act as the motivational tools referring to future L2 self-images; however, learning experience is largely related to the immediate learning context (Papi \& Teimouri, 2014). Overall, the ideal L2 self and the L2 learning experience are argued to be more influential causes of heightened L2 learning motivation (Csizér \& Kormos, 2009; Papi, 2010; Taguchi et al., 2009). Employing L2 motivational self-system as the framework, the researchers of the present study conceptualized ideal L2 writing self as L2 learners' aspired future images of themselves as proficient L2 writers.

With the turn of the century, the emergence of new technology devices has instigated a revival of attention to writing as an integral element of the second language (L2) instruction (Elola \& Oskoz, 2017). Having been regarded as an integral section of modern life, Web 2.0 technology instruments have become widely popular and used by many people for information delivery, communication, discussion, and entertainment (Warschauer \& Grimes, 2007). Unlike Web 1.0 technologies, Web 2.0 technology provides its users with the opportunity to control, direct, self-publish, create, and share information with other people (Fathi \& Torabi, 2019; Wang \& Vásquez, 2012). The contemporary Web 2.0 technologies (e.g., wikis, Moodle, \& blogs) unavoidably require employing writing as a medium of communication, exerting problems for conventional pedagogic approaches which were predominantly concerned with linguistic development. In spite of the recent research attention directed to technology-mediated L2 writing instruction (Kessler, 2009; Oskoz \& Elola, 2014), numerous EFL writing practitioners are still employing the conventional teaching methods with no use of technology devices in their classrooms (Elola \& Oskoz, 2017).

Blog, one alluring Web 2.0 device, is considered as an effective vehicle for exchanging ideas and information and is able to meet different needs of different people in various educational settings (Ducate \& Lomicka, 2005). Concerning L2 pedagogy, blogs have 
recently attracted much research attention (e.g., Alm, 2009; Bakar \& Ismail, 2009; Ducate \& Lomicka, 2005; Lee, 2009; Murray \& Hourigan, 2008; Zhang, 2009). As far as L2 writing is concerned, various scholars have corroborated the usefulness of blogs for enhancing writing competencies (Armstrong \& Retterer, 2008; Dizon \& Thanyawatpokin, 2018; Fathi \& Nourzadeh, 2019; Nguyen, 2012; among others). The effectiveness of blogs in L2 writing is usually associated to their potentials in providing the users with access to the links of other online resources, encouraging further writing practice, providing a real audience to write for, increasing cooperation, fostering autonomous learning, shaping a sense of ownership, building a sense of community, improving learner engagement, and promoting further feedback (Campbell, 2003, 2005; Chen, 2016; Fathi \& Nourzadeh, 2019; Fathi \& Rahimi, 2020; Fellner \& Apple, 2006; Nguyen, 2012; Kusumaningrum, Cahyono, \& Prayogo, 2019; Rahimi \& Fathi, 2021; Safdari \& Fathi, 2020).

Writing in a foreign language is highly affected by individual and psychological variables as they make learners recognize the knowledge they lack, attend to particular aspects of language, and benefit from the learning opportunities created by writing (Kormos, 2012; Piniel \& Csizér, 2015). Affective and psychological variables related to L2 writing can cognitively engage learners, direct their attention, and identify the degree of effort and persistence they may exert to the writing activities (Han \& Hiver, 2018). Given the complex nature of L2 writing as the taxing process requiring appropriate harmonizing of numerous linguistic, cognitive, and affective mechanism (Kellogg, 1996), the extant literature on L2 writing gives much empirical credit to the importance of individual or affective factors influencing and correlating with L2 writing process (Piniel \& Csizér, 2015). However, few empirical studies have ever examined the effect of blog-mediated writing instruction on the writing-related affective variables. More particularly, as far as writing skill is concerned, motivation is considered as one influential affective variable which accounts for "variations in every stage of L2 writing processes and the quality of written product" (Kormos, 2012, p. 101). Nevertheless, exploration of L2 writing motivation appears to be less-addressed on L2 writing research agenda (Csizér \& Tankó, 2015; Kormos, 2012; Waller \& Papi, 2017).

Furthermore, in spite of the fact that numerous studies have explored the effectiveness of blogs in EFL writing classrooms (e.g., Armstrong \& Retterer, 2008; Arslan, \& ŞahinKiz1l, 2010; Chen, 2016; Dizon \& Thanyawatpokin, 2018; Fathi \& Nourzadeh, 2019), real implementation of blog-supported writing instruction in EFL classrooms requires further empirical support. As it is stated by Porte and Richards (2012), since EFL writing is claimed to be so cognitively demanding due to its nature and a wide range of topics, replication studies seem to be legitimate so as to guide the direction of EFL writing studies. In addition, it appears that Iranian EFL instructors in general and writing practitioners in particular still pursue traditional interventions in which the roles of technology devices as well as peer evaluation or feedback have been neglected (e.g., Fathi, Derakhshan, \& Safdari, 2020; Fathi \& Hamidizadeh, 2019; Fathi \& Nourzadeh, 2019). Therefore, in order to shed more light on the effect of blog-mediated writing instruction on the L2 writing-related psychological variables, the goal of this research set out to explore the impact of a blog-mediated writing course on writing performance 
and the ideal writing self of EFL learners in the Iranian context. L2 motivational self system was adopted as the theoretical framework underpinning L2 writing motivation as this theory is conceptualized as "an innovative reformation of the previous L2 motivation theories" (Papi \& Abdollahzadeh, 2012, p. 576) and it can offer a new line of inquiry regarding L2 learning motivation (MacIntyre et al., 2009). Taken together, two research questions guided the purpose of the present study:

1. Does blog-mediated writing instruction significantly improve writing performance of Iranian EFL learners?

2. Does blog-mediated writing instruction significantly enhance the ideal writing self of Iranian EFL learners?

\section{Review of Literature}

As the use Web 2.0 in L2 learning and instruction has gained momentum over the last years (Stevenson \& Liu, 2010; Wang \& Vásquez, 2012), numerous L2 researchers have carried out studies to explore the effectiveness of blogs in L2 writing pedagogy. To ground the goal of this project, a number of more relevant studies examining blogging approach in L2 writing are reviewed in this section. For example, Chen et al. (2020) examined the effect of blog-mediated EFL writing instruction for college students. Two groups of Taiwanese EFL learners served as the subjects who were assigned to the control group, who received conventional writing instruction, and the experimental group, who underwent a blog-mediated English writing instruction. The linguistic performance and attitudes of the two groups were compared. Fluency, accuracy, and lexical complexity were considered as defining elements of linguistic performance. The results obtained from the statistical analyses indicated that the two groups were not substantially different in terms of linguistic performance. Nevertheless, within-group analyses demonstrated that the two groups progressed in terms of writing fluency and accuracy. Furthermore, most participants held positive attitudes towards their experienced instruction. In another study, Arslan and Şahin-Kızıl (2010) carried out a quasi-experimental study to examine the effect of blog-supported instruction on the writing development of EFL students. Fifty Turkish EFL university students served as the study participants who were assigned to the control group, instructed based on faceto-face process-oriented writing approach, and the experimental group, receiving blogsupported process-oriented writing instruction. The findings indicated that the blogmediated writing instruction significantly improved learners' writing skills.

In another study, Vurdien (2013) explored the usefulness of blogging approach for the writing instruction of advanced EFL learner. 11 advanced Spanish learners participated in the treatment lasting for a period of five months. The participants were asked to launch their personal blogs, read each other's opinions, exchange information, and give feedback to the published posts of their peers. The results of the data gathered from the blog entries, group discussions, and questionnaires showed that personal blogs were effective in motivating the participants to improve their writing competencies through thinking and other feedback. Overall, the results showed that blogging approach in writing enhanced the EFL students' writing motivation. Likewise, Lee (2010) explored the usefulness of using blogs in improving L2 writing performance and motivation of L2 
learners. The findings indicated that employing blogs in L2 writing was effective in improving L2 writing fluency and motivation of the learners. Furthermore, the L2 students had positive perceptions of the feedback of their peers and the instructor, particularly the feedback related to the language and form.

Fathi and Nourzadeh (2019) carried out a mixed methods research to scrutinize the impact of the blog-mediated writing instruction on the writing achievement and anxiety of EFL learners. These participants $(\mathrm{N}=46)$ were from two intact university classes who were randomly assigned to the control group, who were taught traditionally, and the experimental group, who received blog-integrated instruction. The findings revealed that blog-mediated writing instruction was useful in improving the writing abilities of the EFL learners. Moreover, the treatment significantly decreased the anxiety of the learners in doing writing tasks. The qualitative phase also showed that the EFL learners had positive perceptions towards blogging in L2 writing. Also, Fathi, Ahmadnejad, and Yousofi (2019) found that the use of blogs in EFL writing instruction was effective in increasing writing motivation and writing self-regulation of the participants. Nevertheless, their blog-mediated writing instruction reduced the writing self-efficacy of the EFL learners. Similarly, Nezakatgoo and Fathi (2019) explored the impact of blogging in L2 writing on the autonomous learning of EFL students. Their results indicated that the learning autonomy of the EFL students was significantly improved due to their experience of blog-mediated instruction.

Similarly, Chen (2016) investigated the usefulness of blogging in affecting metalinguistic and affective performance of EFL learners. Using a quasi-experimental design, the researcher found that there were no significant differences between the two classes regarding metalinguistic strategy use but there were significant differences as far as metalinguistic awareness was concerned. Further exposure, greater interaction and discussion between students, the reverse-chronological archiving of blogs, and employing blogging procedure in the writing course were reported as the factors for enhancing learners' metalinguistic awareness. However, regarding the affective variables, the groups were found to be identical in terms of writing motivation and writing anxiety. The control group, however, significantly performed better as far as writing self-efficacy was concerned.

Also, Özdemir and Aydın (2020) investigated the effect of blogs on writing motivation of Turkish EFL students. Their findings revealed that, the use of blogs alone could not enhance motivation; however, the process-based writing approach significantly contributed to increasing writing motivation of EFL learners. Therefore, the researchers highlighted the role of the context for the effective impacts of blogs in L2 learning. Similarly, Armstrong and Retterer (2008) evaluated the usefulness of blogs in affecting L2 writing achievement, self-confidence, and attitudes among number of college students. In so doing, blog posts were probed and interviews were conducted with the students. The findings showed that the blogging approach enhanced the writing achievement of the participants. Moreover, it was revealed that most participants held positive perceptions towards their experience. 
In a recent study, Lee (2020) conducted a study to investigate the effectiveness of blogging in enhancing L2 writing skills in fully online courses of language. In so doing, 48 beginning L2 learners were encouraged to use blogs for doing their writing tasks. The treatment lasted for a course of two summers. As for data collection, quantitative and qualitative data were obtained from surveys, interviews, blog entries, and comments. The analysis of the data indicated that L2 learners viewed blogging as an effective medium for improving their writing skills. Additionally, it was revealed that scaffolding given by peers helped participants to enhance their writing abilities in terms of content as well as form. Furthermore, Teimournezhad, Sotoudehnama, and Marandi (2020) carried out a study to compare the effect of the traditional mode of journal writing with that of blog-based journal writing on EFL learners' writing competencies. For this purpose, four components of accuracy, fluency, lexical, and syntactic complexity were taken into consideration while evaluating the participants' writing tasks. Overall, it was revealed that blog-based journal writing significantly contributed to EFL learners' quality of writing.

Nevertheless, Lin (2014) criticized the findings of previous studies which had reported the usefulness of blogs in L2 writing classrooms. According to Lin (2014), most of such studies suffered from methodological inadequacies or their findings were overestimated. Two groups of L2 students were recruited as the participants in this study. One group received blog-based instruction, while the other group received in-class traditional instruction. Writing ability, motivation, and self-efficacy beliefs of participants were evaluated as the dependent variables of the study. The findings revealed that no significant differences were found between the groups concerning writing performance and self-efficacy. Moreover, control group were better in terms of learning motivation at the end of the study.

\section{METHOD}

This study employed a quantitative research design. Because the researchers were able to select and divide the participants randomly in this research context, this design is categorized as a true-experimental design (Ary, Jacobs, Sorensen, \& Walker, 2019). The advantage of this design is the fact that it uses randomization and exerts maximum degree of control over extraneous variables.

\section{Participants}

To address the objective of this research, a number of 47 female, intermediate EFL learners were recruited as the participants. These EFL learners were chosen from about 70 intermediate learners in a big private language school in Tehran, Iran. As for the screening of the participants and to ensure their homogeneity in terms of general English proficiency, a retired version of TOEFL was administered to them. Next, 47 learners whose scores lay within the range of one standard deviation below and above the mean were selected as the final participants of the study. These students were randomly assigned to an experimental group $(\mathrm{N}=24)$ who were taught writing with the mediation of blogs and a control group $(\mathrm{N}=23)$ who received the conventional writing instruction. All the students were female and their age varied from 21 to 24. Although the students 
were familiar with blogs, they had not previously used blogging for educational purposes. These participants had enrolled in the writing course whose purpose was to improve the integral writing skills for the intermediate EFL learners.

\section{Instruments}

\section{Language Proficiency Test}

As the global language proficiency may influence affective variables of L2 writing, a retired version of TOEFL (2006) was given to the students. Then, a homogeneous sample of participants were selected. This version of TOEFL included two sections of Structure as well as Written Expressions and Reading Comprehension. Each section consisted of 30 multiple choice items. The internal consistency coefficient of this version of TOEFL was computed via Cronbach Alpha formula. The calculated reliability coefficient turned out to be high $(\mathrm{r}=.83)$.

\section{Ideal L2 Writing Self Scale}

Ideal L2 Writing Self Scale designed by Han and Hiver (2018) was used to measure L2 learners' aspired future images of themselves as capable writers. The scale includes six items (see Appendix) which were adapted from Taguchi, Magid, and Papi (2009) (as cited in Han \& Hiver, 2018). The scale was assessed employing a six-point response scale, varying from 1 (Never) to 6 (always). The reliability coefficient of the scale, as estimated by Cronbach's Alpha formula, was calculated to be 0.88 in the current research.

\section{Timed-writing tasks}

The writing performance of the participants was assessed using two 40-minute writing tasks which were administered to the participants of both groups. The reason for using Timed writing tasks was the fact that they have been shown to measure students' writing ability more accurately (Datchuk, 2017). These tasks served as the pre-test (Topic A) and post-test (Topic B) of the study.

Topic A: Is money the most important aspect of a job?

Topic B: Do grades encourage students to learn?

\section{Data Collection Procedure}

As the first step and prior to the writing course, a timed-writing task (Topic A) was administered to the participants as the pre-test. In addition, the Ideal L2 Writing Self scale was administered to the participants of both groups as the pre-test.

Within a period of 12 weeks, the control group and the experimental group received writing instruction by the same teacher who used the identical materials. The purpose of the writing course was to familiarize the students with process writing approach. The students were instructed to recognize and identify the main writing structures from model paragraphs to essays. Then they were required to practice the structures in short, manageable writing activities. They were finally asked to apply the learned techniques 
and structures to their own writing. The students were also given opportunities to carry out the tasks independently or to work with a partner, or with a group. The tasks and exercises could be done in class or at home. The instructor tried to raise the critical thinking of the participants in order to make them more conscious of the usefulness of their choice of vocabularies, structures, sentences, and rhetorical organizations on the quality of their writing.

As far as the experimental condition of the study was concerned, the students received the essential explanations and instructions to create their own weblogs through https://www.edublogs.org. They were taught how to publish posts, comment on posts, and see the archived pages. The class blog also provided the students with access to other blogs or websites including useful information on L2 writing as well as list of most needed vocabularies and grammatical structures. The participants were required to publish their written tasks on the blogs and exchange comments and knowledge with the teacher and classmates throughout cyberspace. They were also asked to give frequent feedback to their peers and comment on their tasks. Therefore, the participants could receive corrective feedback from both the teacher and their peers. The participants of the experimental group could have discussion and interaction about the issues related to writing and the completed tasks.

With regard to the control group instruction, the same materials and the same tasks and homework were also employed for the participants. These students received the same process writing approach including the key steps of writing: drafting, feedback, and editing. However, the students in the control group did not use blogging approach or any technology devices for doing writing tasks. The participants in the control group were asked to keep all the essays and writing tasks in a paper-and-pencil format. During the course, the students were given the opportunities to discuss tasks and sample essays of their classmates inside the class. At the end of the writing course, the other timed writing task (Topic B) was administered to the participants of both groups as the post-tests of the study. Also, the same Ideal L2 Writing Self scale was re-administered to the participants of both groups as the post-test of the study.

\section{Data Analysis}

To address the statistical analyses of this research, SPSS (Version 22) was drawn upon. To probe the impac of blogging on writing and self-efficacy, the researchers used both descriptive and inferential statistics. With regard to the descriptive statistics, mean and standard deviations of the scores of writing performance and the ideal L2 writing self in both pre-test and post-test were investigated. As far as the inferential statistics was concerned, paired-samples t-tests and one-way analysis of covariance (ANCOVA) were performed in order to compare the effect of blog-mediated writing instruction and the impact of traditional, inside-the-class instruction on the writing performance and ideal writing self of the EFL participants.

Additionally, Jacobs et al.'s (1981) writing scale was used to score the essays of the participants. This writing rubric is claimed to have high validity as its outlined criteria assess the performance of EFL/ESL students' various kinds of expository writing that 
are writing activities they carry out in the foreign language contexts (Bacha, 2001). This scale is an analytical rating rubric by which a writing task is rated against a set of five criteria. To guarantee the inter-rater reliability of the rated tasks, about 25 percent of the writing tasks were corrected by another colleague who had been trained with this scoring rubric. The scores of the independent rater and those of the researchers were subjected to Cohen's Kappa's inter-rater reliability test. The calculated reliability coefficient was reported to be 0.83 .

Table 1

Paired samples t-test for writing performance scores

\begin{tabular}{|c|c|c|c|c|c|c|}
\hline & & Pre-test & & & & \\
\hline $\begin{array}{l}\text { Groups } \\
\text { Sig. }\end{array}$ & & $\mathrm{M}$ & SD & $\mathrm{M}$ & SD & $\mathrm{t}$ \\
\hline Experimental & 54.75 & 11.39 & 75.74 & 10.9 & -12.16 & 0.00 \\
\hline Control & 57.60 & 12.73 & 67.78 & 11.85 & -2.90 & 0.00 \\
\hline
\end{tabular}

\section{FINDINGS}

Concerning the data analysis for the first research question, paired samples $t$-tests were conducted in order to investigate the progress in the scores of the writing performance in both groups from the pre-test to the post-test. The results of paired samples t-tests indicated a significant increase in the writing performance mean scores for the participants of both groups from the pre-test to post-test. As seen in Table 1, the changes in the writing performance mean score for the experimental group was statistically significant $(\mathrm{t}(23)=-12.16, \mathrm{p}<0.01)$. By the same token, a significant change was observed in the mean scores of the writing performance for the control group $(\mathrm{t}(22)=-$ $2.90, \mathrm{p}<0.01)$. More precisely, the descriptive statistics also revealed that the mean score of writing performance for the experimental group was $54.75(\mathrm{SD}=11.39)$ in the pre-test and it was raised to $75.74(\mathrm{SD}=10.9)$ in the post-test, emphasizing that the increase was statistically significant. Similarly, the writing performance mean score for the control group was raised from $57.60(\mathrm{SD}=12.73)$ to $67.78(\mathrm{SD}=11.85)$ from pretest to the post-test, respectively. This change was also statistically significant.

Furthermore, to exactly explore the effect of blog-mediated writing instruction on the writing performance of the participants in the experimental and control groups, a oneway ANCOVA was carried out. Participants' scores of writing performance in the posttest were regarded as the dependent variable, scores of writing performance in the pretest were considered as the covariate, and the group (traditional vs. blog-mediated) was considered as the independent variable of this study. As the initial analyses of ANCOVA, some preliminary assumptions were checked. In addition, the normality of writing performance scores, calculated via Kolmogrov-Smirnov test, verified the normality of the scores for both blog-based $(F=.53, p=.43)$ and traditional $(F=.25, p$ $=.21$ ) classrooms. Furthermore, the Levene's test for homogeneity of variance demonstrated the equality of variances: there was no significant difference between the variance of the two groups, $(F=6.232, p=.49)$. Also, it was found that the interaction between the covariate (pre-test scores of writing) and independent variable (instruction type) was not significant $(F=41.23, p=.46)$. 
Table 2

The results of ANCOVA for writing performance

\begin{tabular}{lllllll}
\hline Source & $\begin{array}{l}\text { Type III Sum } \\
\text { of Squares }\end{array}$ & df & Mean Square & F & Sig. & $\begin{array}{l}\text { Partial Eta } \\
\text { Squared }\end{array}$ \\
\hline Covariate (pre-test) & 19.324 & 1 & 19.324 & .273 & .604 & .006 \\
\hline Between-subjects & 693.510 & 1 & 693.510 & 9.789 & .003 & .182 \\
\hline Within-subjects & 3117.089 & 44 & 70.843 & & &
\end{tabular}

After ensuring that the assumptions of ANCOVA were not violated, ANCOVA was performed. As Table 2 indicates, the two groups were significantly different in terms of writing skill, $F(1,44)=9.78, p=0.003$, partial eta squared $=0.18)$, suggesting that the writing skill of the EFL learners in the blog group improved greater than the those in the traditional class. These results revealed that blog-based writing course significantly boosted writing skill of the participants.

With regard to the statistical analyses of the second research question, paired samples $t$ tests were first run in order to probe the statistical significance of the degree of change in the scores of the ideal writing self of the EFL students in the two groups from the pretest to the post-test. As indicated by the results of paired samples t-tests, there was a statistically significant increase in the mean scores of the ideal writing self for the participants of both groups from pre-test to post-test. As seen in Table 3, the increase in the mean scores of ideal writing self for the experimental group was statistically significant $(\mathrm{t}(23)=-5.39, \mathrm{p}<0.01)$. Similarly, a statistically significant increase was observed in the mean scores of ideal writing self for the control group $(\mathrm{t}(22)=-3.58, \mathrm{p}<$ $0.01)$. More precisely, the descriptive statistics also showed that the mean score of ideal writing self for the experimental group was $18.25(\mathrm{SD}=4.52)$ in the pre-test and it was raised to 24.77 ( $\mathrm{SD}=4.35$ ) in the post-test, corroborating the fact that the increase was statistically significant. In the same vein, the mean score of the ideal writing self in the pre-test for the control group increased from $19.47(\mathrm{SD}=3.69)$ to $21.41(\mathrm{SD}=3.26)$ on the post-test, suggesting a statistically significant increase.

Table 3

Paired samples $t$-test for ideal writing self scores

\begin{tabular}{|c|c|c|c|c|c|c|}
\hline & \multicolumn{2}{|c|}{ Pre-test } & & \multicolumn{2}{|c|}{ Post-test } & \\
\hline $\begin{array}{l}\text { Groups } \\
\text { Sig. }\end{array}$ & $\overline{\mathrm{M}}$ & SD & & $\mathrm{M}$ & SD & $\mathrm{t}$ \\
\hline Experimental & 18.25 & 4.52 & 24.77 & 4.35 & -5.399 & 0.00 \\
\hline Control & 19.47 & 3.69 & 21.41 & 3.26 & -3.582 & 0.02 \\
\hline
\end{tabular}

Concerning the inferential statistics analyses, to explore the effect of blog-mediated writing instruction on ideal writing

self of the EFL learners, a one-way ANCOVA was carried out. In this analysis, participants' ideal writing self scores in the post-test served as the dependent variable, ideal writing self scores in the pre-test were considered as the covariate, and the group (conventional vs. blog-mediated) was viewed as the independent variable of this research. Prior to running ANCOVA, a number of required assumptions such as 
checking the normality of the score distribution, equality of variance, and the lack of a significant interaction between the covariate (ideal writing self scores in the pretest) and the independent variable (group/type of intervention) were checked. In addition, the normality of ideal writing self scores, checked by Kolmogrov-Smirnov test, verified the normality of the scores for both experimental $(F=.38, p=.24)$ and control $(F=.22, p=$ .18) groups. Furthermore, the Levene's test for homogeneity of variance showed the equality of variances and no significant difference was found between the variance of the two groups, $(F=6.01, p=.47)$. Moreover, the interaction between the covariate (pre-test scores of ideal self) and independent variable (type of intervention) was not significant $(F=40.72, p=.357)$.

Table 4

The results of ANCOVA for ideal writing self

\begin{tabular}{|c|c|c|c|c|c|c|}
\hline Source & $\begin{array}{l}\text { Type III Sum } \\
\text { of Squares }\end{array}$ & $\mathrm{df}$ & Mean Square & $\mathrm{F}$ & Sig. & $\begin{array}{l}\text { Partial Eta } \\
\text { Squared }\end{array}$ \\
\hline Covariate (pre-test) & 59.735 & 1 & 59.735 & 4.413 & .041 & .091 \\
\hline Between-subjects & 158.076 & 1 & 158.076 & 11.678 & .001 & .210 \\
\hline Within-subjects & 595.580 & 44 & 13.536 & & & \\
\hline
\end{tabular}

After checking the preliminary assumptions, ANCOVA was performed. As Table 4 indicates, a statistically significant difference was observed between the two groups in terms of ideal writing self, $F(1,44)=11.678, p=0.001$, partial eta squared $=0.210$ ), confirming that the learners from the blog-mediated class outperformed those of control condition on the post-test of ideal writing self. These results revealed that blog-mediated writing instruction significantly contributed to improving ideal writing self of the Iranian EFL students.

\section{DISCUSSION}

In order to further clarify the utility of Web 2.0 devices and applications in L2 learning, the present research sought to investigate the effect of blog-mediated writing instruction on writing performance and ideal writing self of Iranian EFL learners. The findings from the ANCOVA for the research question one revealed that blog-mediated writing instruction had a greater positive influence on developing writing skill of the EFL learners. This finding corroborates those of numerous studies reported in the literature (e.g., Arslan \& Şahin-Kızıl, 2010; Chen, 2016; Dizon \& Thanyawatpokin, 2018; Fathi \& Nourzadeh, 2019; Lee, 2010; Pham \& Usaha, 2016; Sun, 2010). In line with the findings of Arslan and Şahin-Kızıl (2010), it may be stated that the blog-mediated instruction gave the EFL learners further writing input by providing the participants with more access to other online materials. Further exposure to language input might have improved the writing performance of the participants. In other words, because of posting the writing tasks on the blogs, the EFL writers could have more opportunity to practice writing and get exposed to written input. The effectiveness of blogs in improving writing quality through giving more language input has been widely acknowledged in L2 writing research (Chen, 2016; Fathi \& Nourzadeh, 2019; Zhang, 2009; among others). 
Additionally, as reported by Li (2018), the blogging approach allowed the EFL writers to have constructive interaction about tasks, to receive and give feedback to one another, and to reflect on their own weaknesses and strengths in writing. This collaborative nature of blogging approach is justified in light of collaborative learning (Vygotsky, 1978) in which learning can be facilitated if it is mediated and scaffolded by others. As it was reported by Fathi and Nourzadeh (2019), giving and receiving peer feedback led to further interactions among the learners, which helped the students to enhance their writing. By the same token, since the students of the experimental group could receive greater feedback by others through blogging approach, they could have improved their writing quality by taking the comments and feedback of others into consideration. Moreover, since the participants of the blog-mediated group anticipated the feedback and evaluations of others, they became more careful and attentive to what they wrote and tried more to improve the quality of their drafts.

Concerning research question two, the results revealed that the use of blogs in the writing course was significantly effective in fostering ideal L2 writing self or motivated writing behavior of the participants. In fact, motivated writing behavior was operationally measured by ideal L2 writing self which was characterized as the aspired participants' future images of themselves as proficient and capable L2 writers. The findings of this study are in agreement with those of some studies reported in the literature (e.g., Armstrong \& Retterer, 2008; Chen et al., 2020; Fathi \& Nourzadeh, 2019; Lee, 2010; Nezakatgoo \& Fathi, 2019), which corroborated the usefulness of employing blogs for L2 writing pedagogy. With regard to the particular dependent variable of this study, the present findings support those of other studies (e.g., Chen et al., 2020; Fathi et al., 2019; Özdemir \& Aydın, 2020; Vurdien, 2013), which reported the effectiveness of blog-mediated instruction in improving writing motivation of L2 learners. Nevertheless, the present results are at variance with the findings of Chen (2016) and Lin (2014) who did not verify the usefulness of blogs in L2 writing courses. As discussed before, L2 writing is much influenced by psychological and affective constructs since they enable L2 writers recognize their lacking knowledge, attend to the form of language, and take advantage of the learning chances provided by writing (Piniel \& Csizér, 2015). From this perspective, ideal L2 writing self or motivated writing behaviour is conceptualized as a key affective factor which can elucidate "variations in every stage of L2 writing processes and the quality of written product" (Kormos, 2012, p. 101).

It can be argued that the experiences afforded the participants through the blog-mediated writing instruction are likely to have aided the EFL writers in improving their writing evaluation, gaining positive writing-specific attitudes, enhancing their self-belief and confidence, establishing heightened success expectation, and finally developing better aspired future picture of themselves as competent L2 writers. This is particularly in line with the findings of Fathi et al. (2019), who found that blog-mediated writing instruction enhanced EFL participants' confidence, positive attitudes, and writing motivation.

Additionally, the EFL learners in the blog group were provided with further opportunity to write on the blog and, since they received further and quicker feedback, they exerted 
further attempt to revise and improve their written tasks. These further attempts and practices contributed to improving participants' motivated writing behavior by encouraging the EFL learners to wish to become better writers in the future. Furthermore, anticipation of other-evaluation and receiving corrective feedback from classmates and the teacher might have increased the motivation of participants of the experimental group to produce high-quality written tasks. Blogging might have created a friendly atmosphere for the participants where they could read, write and comment on others' published written tasks. They could also write what they wished to write and had control over their tasks since they could do them at home without time constraints. These features of blogs are likely to have increased the writing motivation of the participants. Also, blogging approach employed by the experimental group might have created a small learning community in which members could collaboratively set objectives, get more engaged in doing tasks, and correct each other, thereby creating a more powerful sense of community (Efimova \& Fiedler, 2003; Godwin-Jones, 2003; Wegner, 1998), which contributed to improving motivated writing behavior of the participants.

As the participants could receive more frequent and quicker feedback by posting on the blog, their writing learning process was scaffolded by the teacher or peers. Such kind of assistance and scaffolding might have encouraged the participants to develop useful strategies to regulate their own learning process and gain further confidence in doing written tasks (Csizér \& Tankó, 2017), thereby improving their ideal self in doing written tasks. In addition, this finding also corroborates the assumption that learners who cooperate and learn collectively are more likely to have better learning outcomes via collective consciousness as well as through cooperation with more knowledgeable peers (Hyland, 2007).

\section{CONCLUSION}

The aim of the current research was to explore the usefulness of blogging in EFL writing courses. Taken together, the results of the current research revealed that the use of blogs in EFL writing instruction helped participants to project a more ideal image of the themselves as more competent writers in future. In other words, the blog-mediated instruction contributed to enhancing the integrative and intrinsically instrumental motives for improving L2 writing of the participants. Concerning the theoretical implications, addressing affective and motivational constructs of L2 writing may open a new avenue into the intricate associations of affective variables and cognitive outcomes (i.e., linguistic performance) of L2 writing research agenda. From pedagogical point of view, the findings of this study shed more light on the effectiveness of technologyassisted writing instruction in EFL contexts. More particularly, the integration of blogs in L2 pedagogy might be suggested as and effrective and viable type of blended learning approach which can result in better linguistic and affective outcomes. As a result, L2 teacher development programs should take serious actions in order to train pre-service L2 practitioners to integrate technology devices into their own EFL curriculums. Such successful use of technology for educational purposes requires effective synchronization of pedagogic knowledge, content knowledge, and proper use of technology in teaching 
(Fathi \& Yousefifard, 2019). Therefore, as Fathi and Ebadi (2020) maintained, an effective teacher development program which intends to encourage successful integration of technology in EFL contexts should not only allow prospective teachers to have immediate experience of employing technology devices "but it also includes providing them with ample opportunities and a kind of internship to develop the knowledge of using technology for teaching EFL appropriately and effectively" (p.19).

As far as limitations of this study are concerned, some concerns can be pointed out. The data of the present study were quantitative and obtained from a small-scale project, hence; the results may lack adequate external validity. Future researchers are suggested to employ qualitative research methods to explore the reasons and underlying causes of how and why blog-mediated instruction can influence writing-related variables of EFL learners. Since replication studies on L2 writing issues are warranted (Porte, \& Richards, 2012), further empirical evidence on the effects of blogging approach on L2 writing is required to increase the generalizibility of the findings. To this end, similar studies should be replicated employing larger samples of participants with various language proficiency levels in various learning contexts. Finally, all the psarticipants of the present study were female EFL learners. Next researchers can widen the scope of this research base by considering gender as the potential moderator variable.

\section{REFERENCES}

Alm, A. (2009). Blogging for self-determination with L2 learner journals. In Handbook of research on Web 2.0 and second language learning (pp. 202-222). IGI Global. https://doi.org/10.4018/978-1-60566-190-2.ch011

Armstrong, K. \& Retterer, O. (2008). Blogging as L2 writing: A case study. AACE Journal, 16(3), 233-251.

Arslan, R. Ş., \& Şahin-Kızıl, A. (2010). How can the use of blog software facilitate the writing process of English language learners? Computer Assisted Language Learning, 23(3), 183-197. https://doi.org/10.1080/09588221.2010.486575

Ary, D., L. C. Jacobs, C. Sorensen, \& D. Walker. (2019). Introduction to Research in Education. (10th ed.). Boston, MA: Cengage.

Bacha, N. (2001). Writing evaluation: what can analytic versus holistic essay scoring tell us?. System, 29(3), 371-383.

Bakar, N. A., Ismail, K. (2009). Using blogs to encourage ESL students to write constructively in English. Journal of Teaching and Learning in Higher Education, l(1). 45-57.

Campbell, A.P. (2003). Weblogs for use with ESL classes. The Internet TESL Journal, 9(2). Retrieved fromhttp://iteslj.org/Techniques/Campbell-logs.html

Campbell, A. (2005). 'Weblog applications for EFL/ESL classroom blogging: a comparative review'. TESL-EJ, 9(3), 1-12. 
Chen, P. J. (2016). Learners' metalinguistic and affective performance in blogging to write. Computer Assisted Language Learning, 29(4), 790-814. https://doi.org/10.1080/09588221.2015.1068813

Chen, P. J., Cheng, Y. S., \& Lin, C. C. (2020). Blogging to learn to write in an EFL context: A comparison study. US-China Education Review, 10(1), 20-34. https://doi.org/10.17265/2161-623X/2020.01.003

Csizér, K., \& Kormos, J. (2009). Learning experiences, selves and motivated learning behavior: A comparative analysis of structural models for Hungarian secondary and university learners of English. In Z. Dörnyei \& E. Ushioda (Eds.), Motivation, language identity and the L2 self (pp. 9-42). Clevedon: Multilingual Matters. https://doi.org/10.21832/9781847691293-006

Csizér, K., \& Tankó, G. (2017). English majors' self-regulatory control strategy use in academic writing and its relation to L2 motivation. Applied Linguistics, 38, 386-404.

Datchuk, S. M. (2017). A direct instruction and precision teaching intervention to improve sentence construction of middle school students with writing difficulties. Journal of Special Education, 51, 62-71. https://doi:10.1177/0022466916665588

Dizon, G., \& Thanyawatpokin, B. (2018). Web 2.0 tools in the EFL classroom: Comparing the effects of Facebook and blogs on L2 writing and interaction. The EuroCALL Review, 26(1), 29-42. https://doi.org/10.4995/eurocall.2018.7947

Dörnyei, Z. (2005). The psychology of the language learner: Individual differences in second language acquisition. Mahwah, NJ: Erlbaum. https://doi.org/10.1177/0261927X05281424

Dörnyei, Z. (2009). The L2 motivational self system. In Z. Dörnyei \& E. Ushioda (Eds.), Motivation, language identity and the L2 self (pp. 9-42). Clevedon: Multilingual Matters. https://doi.org/10.21832/9781847691293-003

Dörnyei, Z., \& Ushioda, E. (2009). Motivation, language identities and the L2 self: Future research directions. In Z. Dörnyei \& E. Ushioda (Eds.), Motivation, language identity and the L2 self (pp. 350-356). Clevedon: Multilingual Matters. https://doi.org/10.21832/9781847691293

Ducate, L., \& Lomicka, L. (2008). Adventures in the blogosphere: From blog readers to blog writers. Computer Assisted Language Learning, 21(1), 9-28. https://doi.org/10.1080/09588220701865474

Efimova, L., \& Fiedler, S. (2003). Learning webs: Learning in weblog networks. In P. Kommers, P. Isaias, \& M. B. Nunes (Eds.), Proceedings of the IADIS International Conference Web Based Communities 2004 (pp.490-494), Lisbon: IADIS Press.

Elola, I., \& Oskoz, A. (2017). Writing with 21st century social tools in the L2 classroom: New literacies, genres, and writing practices. Journal of Second Language Writing, 36, 52-60. https://doi.org/10.1016/j.jslw.2017.04.002 
Fathi, J., Ahmadnejad, M., \& Yousofi, N. (2019). Effects of blog-mediated writing instruction on L2 writing motivation, self-Efficacy, and self-Regulation: A mixed methods study. Research in Applied Linguistics, 10(2), 159-181.

Fathi, J., Derakhshan, A., \& Safdari, M. (2020). The impact of portfolio-based writing instruction on writing performance and anxiety of EFL students. Polish Psychological Bulletin, 226-235.

Fathi, J., \& Ebadi, S. (2020). Exploring EFL pre-service teachers' adoption of technology in a CALL program: obstacles, motivators, and maintenance. Education and Information Technologies, 1-21.

Fathi, J., \& Hamidizadeh, R. (2019). The contribution of listening strategy instruction to improving second language listening comprehension: A case of Iranian EFL learners. International Journal of Instruction, 12(2), 17-32.

Fathi, J., \& Nourzadeh, S. (2019). Examining the effects of writing instruction through blogging on second language writing performance and anxiety. Issues in Language Teaching, 8(1), 63-91.

Fathi, J., \& Rahimi, M. (2020). Examining the impact of flipped classroom on writing complexity, accuracy, and fluency: A case of EFL students. Computer Assisted Language Learning, 1-39.

Fathi, J., \& Torabi, S. (2019). The contribution of a Course Management System (CMS)-supported instruction to developing grammar performance: A case of Iranian EFL learners. CALL EJ, 20(2), 89-98.

Fathi, J., \& Yousefifard, S. (2019). Assessing language teachers' Technological Pedagogical Content Knowledge (TPACK): EFL students' perspectives. Research in English Language Pedagogy, 7(2), 255-282.

Fellner, T., \& Apple, M. (2006). Developing writing fluency and lexical complexity with blogs. The JALT CALL Journal, 2(1), 15-26. https://doi.org/10.29140/jaltcall.v2n1.19

Gardner, R. C. (1985). Social psychology and second language learning: The role of attitudes and motivation. London: Arnold.

Gardner, R. C. (2001). Integrative motivation and second language acquisition. In Z. Dörnyei \& R. Schmidt (Eds.), Motivation and second language acquisition (pp. 1-20). Honolulu: University of Hawaii, Second Language Teaching and Curriculum Center.

Gardner, R. C., \& MacIntyre, P. D. (1993). A student's contributions to secondlanguage learning. Part II: Affective variables. Language Teaching, 26, 1-11.

Godwin-Jones, B. (2003). Emerging technologies: Blogs and wikis: Environments for on-line collaboration. Language Learning \& Technology, 7(2), 12-16. 
Han, J., \& Hiver, P. (2018). Genre-based L2 writing instruction and writing-specific psychological factors: The dynamics of change. Journal of Second Language Writing, 40, 44-59. https://doi.org/10.1016/j.jslw.2018.03.001

Henry, A. (2020). Possible selves and personal goals: What can we learn from episodic future thinking?. Eurasian Journal of Applied Linguistics, 6(3), 481-500. https://doi.org/10.32601/ejal.834659

Higgins, E. T. (1987). Self-discrepancy: A theory relating self and affect. Psychological Review, 94, 319-340. https://doi.org/10.1037/0033-295X.94.3.319

Hyland, K. (2007). Genre pedagogy: Language, literacy and L2 writing instruction. Journal of second language writing, 16(3), 148-164. https://doi.org/10.1016/j.jslw.2007.07.005

Kessler, G. (2009). Student-initiated attention to form in wiki-based collaborative writing. Language Learning \& Technology, 13(1), 79-95.

Kim, T. Y., \& Kim, Y. (2020). Structural Relationship Between L2 Learning Motivation and Resilience and Their Impact on Motivated Behavior and L2 Proficiency. Journal of Psycholinguistic Research, 1-20. https://doi.org/10.1007/s10936-020-09721-8

Kormos, J. (2012). The role of individual differences in L2 writing. Journal of Second Language Writing, 21, 390-403. https://doi.org/10.1016/j.jslw.2012.09.003

Kellogg, R. T. (1996). A model of working memory in writing. In C. M. Levy \& S. Ransdell (Eds.), The science of writing: Theories, methods, individual differences and applications (pp. 57-71). Mahwah, NJ: Lawrence Erlbaum.

Kusumaningrum, S. R., Cahyono, B. Y., \& Prayogo, J. A. (2019). The effect of different types of peer feedback provision on EFL students' writing performance. International Journal of Instruction, 12(1), 213-224.

Lee, L. (2009). Promoting intercultural exchanges with blogs and podcasting: A study of Spanish-American telecollaboration. Computer Assisted Language Learning, 22(5), 425-443. https://doi.org/10.1080/09588220903345184

Lee, L. (2010). Fostering reflective writing and interactive exchange through blogging in an advanced language course. ReCALL, 22(2), 212-227. https://doi.org/10.1017/S095834401000008X

Lee, L. (2020). An exploratory study of using personal blogs for L2 writing in fully online language courses. In Recent Developments in Technology-Enhanced and Computer-Assisted Language Learning (pp. 145-163). IGI Global. https://doi.org/10.4018/978-1-7998-1282-1.ch007

Li, M. (2018). Computer-mediated collaborative writing in L2 contexts: An analysis of empirical research. Computer Assisted Language Learning, 1-23. https://doi.org/10.1080/09588221.2018.1465981 
Lin, M. H. (2014). Effects of classroom blogging on ESL student writers: An Empirical reassessment. The Asia-Pacific Education Researcher, 23(3), 577-590. https://doi.org/10.1007/s40299-013-0131-8

Lomicka, L., \& Lord, G. (2009). Introduction to social networking, collaboration, and Web 2.0 tools. In L. Lomicka \& G. Lord (Eds.), The next generation: Social networking and online collaboration in foreign language learning (pp. 1-11). San Marcos, Texas: CALICO.

MacIntyre, P. D., Mackinnon, S. P., \& Clément, R. (2009). The baby, the bathwater, and the future of language learning motivation research. In Z. Dörnyei \& E. Ushioda (Eds.), Motivation, language identity and the L2 self (pp. 43-65). Clevedon: Multilingual Matters. https://doi.org/10.21832/9781847691293-004

Marcus, H., \& Nurius, P. (1986). Possible selves. American Psychologist, 41, 954-969. https://doi.org/10.1037/0003-066X.41.9.954

Murray, L., \& Hourigan, T. (2008). Blogs for specific purposes: Expressivist or sociocognitivist approach?. ReCALL: the Journal of EUROCALL, 20(1), 82. https://doi.org/10.1017/S0958344008000719

Nezakatgoo, B. \& Fathi, J. (2019). Second language writing through blogs: An investigation of learner autonomy. Iranian Journal of Applied Language Studies, 11(2), 131-160.

Nguyen, P. T. T. (2012). Peer feedback on second language writing through blogs: The case of a Vietnamese EFL classroom. International Journal of Computer-Assisted Language Learning and Teaching (IJCALLT), 2(1), 13-23. https://doi.org/10.4018/ijcallt.2012010102

Nourzadeh, S., Fathi, J., \& Davari, H. (2020). An examination of Iranian learners' motivation for and experience in learning Korean as an additional language. International Journal of Multilingualism, 1-15. https://doi.org/10.1080/14790718.2020.1850736

Özdemir, E., \& Aydın, S. (2020). Blogging effect on English as a Foreign Language writing motivation: Blogging and writing motivation. In Language Learning and Literacy: Breakthroughs in Research and Practice (pp.248-268). Hershey, PA: IGI Global. https://doi.org/10.4018/978-1-5225-9618-9.ch013

Oskoz, A., \& Elola, I. (2014). Promoting foreign language collaborative writing through the use of Web 2.0 tools and tasks. In M. González-Lloret, \& L. Ortega (Eds.), Technology-mediated TBLT: Researching technology and tasks (pp. 115-147). Philadelphia, PA: John Benjamins. https://doi.org/10.1075/tblt.6.05osk

Papi, M. (2010). The L2 motivational self system, L2 anxiety, and motivated behavior: A structural equation modeling approach. System, 38, 467-479. https://doi.org/10.1016/j.system.2010.06.011 
Papi, M., \& Abdollahzadeh, E. (2012). Teacher motivational practice, student motivation, and possible L2 selves: An examination in the Iranian EFL context. Language Learning, 62, 571-594. https://doi.org/10.1111/j.1467-9922.2011.00632.x

Papi, M., \& Teimouri, Y. (2014). Language learner motivational types: A cluster analysis study. Language Learning, 64, 493-525. https://doi.org/10.1111/lang.12065

Pham, V. P. H., \& Usaha, S. (2016). Blog-based peer response for L2 writing revision. $\begin{array}{llll}\text { Computer Assisted Language Learning, 29(4), 724-748. } & \end{array}$ https://doi.org/10.1080/09588221.2015.1026355

Piniel, K., \& Csizér, K. (2015). Changes in motivation, anxiety and self-efficacy during the course of an academic writing seminar. Motivational dynamics in language learning, 164-194. https://doi.org/10.21832/9781783092574-015

Porte, G., \& Richards, K. (2012). Focus article: Replication in second language writing research. Journal of Second Language Writing, 21(3), 284-293.

Rahimi, M., \& Fathi, J. (2021). Exploring the impact of wiki-mediated collaborative writing on EFL students' writing performance, writing self-regulation, and writing selfefficacy: a mixed methods study. Computer Assisted Language Learning, 1-48.

Safdari, M., \& Fathi, J. (2020). Investigating the role of dynamic assessment on speaking accuracy and fluency of pre-intermediate EFL learners. Cogent Education, $7(1), 1818924$.

Stevenson, M. P., \& Liu, M. (2010). Learning a language with Web 2.0: Exploring the use of social networking features of foreign language learning websites. CALICO journal, 27(2), 233. https://doi.org/10.11139/cj.27.2.233-259

Sun, Y. C. (2010). Extensive writing in foreign-language classrooms: A blogging approach. Innovations in Education and Teaching International, 47(3), 327-339. https://doi.org/10.1080/14703297.2010.498184

Taguchi, T., Magid, M., \& Papi, M. (2009). The L2 motivational self system amongst Chinese, Japanese, and Iranian learners of English: A comparative study. In Z. Dörnyei \& E. Ushioda (Eds.), Motivation, language identity and the L2 self (pp. 66-97). Clevedon: Multilingual Matters. https://doi.org/10.21832/9781847691293-005

Teimournezhad, S., Sotoudehnama, E., \& Marandi, S. S. (2020). Exploring the effect of paper-and-pencil vs. blog JW on L2 writing in terms of accuracy, fluency, lexical complexity, and syntactic complexity. Journal of English Language Teaching and Learning, 12(25), 289-321.

Vurdien, R. (2013). Enhancing writing skills through blogging in an advanced English as a Foreign Language class in Spain. Computer Assisted Language Learning, 26(2), 126-143. https://doi.org/10.1080/09588221.2011.639784

Vygotsky, L. (1978). Interaction between learning and development. Readings on the development of children, 23(3), 34-41. 
Waller, L., \& Papi, M. (2017). Motivation and feedback: How implicit theories of intelligence predict L2 writers' motivation and feedback orientation. Journal of Second Language Writing, 35, 54-65. https://doi.org/10.1016/j.jslw.2017.01.004

Wang, S., \& Vásquez, C. (2012). Web 2.0 and second language learning: What does the research tell us? Calico Journal, 29(3), 412-430. https://doi.org/10.11139/cj.29.3.412430

Warschauer, M., \& Grimes, D. (2007). Audience, authorship, and artifact: The emergent semiotics of Web 2.0. Annual Review of Applied Linguistics, 27, 1. https://doi.org/10.1017/S0267190508070013

Wenger, E. (1998). Communities of practice: Learning, meaning, and identity, New York, NY: Cambridge University Press. https://doi.org/10.1017/CBO9780511803932

Yang, E.-M. (2011). Korean college students' English learning motivation and listening proficiency. English Language \& Literature Teaching, 17(2), 93-114.

Zhang, D. (2009). The application of blog in English writing. Journal of Cambridge Studies, 4(1), 64-72.

Zhang, X., Dai, S., \& Ardasheva, Y. (2020). Contributions of (de) motivation, engagement, and anxiety to English listening and speaking. Learning and Individual Differences, 79, 101856. https://doi.org/10.1016/j.lindif.2020.101856

\section{APPENDIX}

Ideal L2 Writing Self Scale

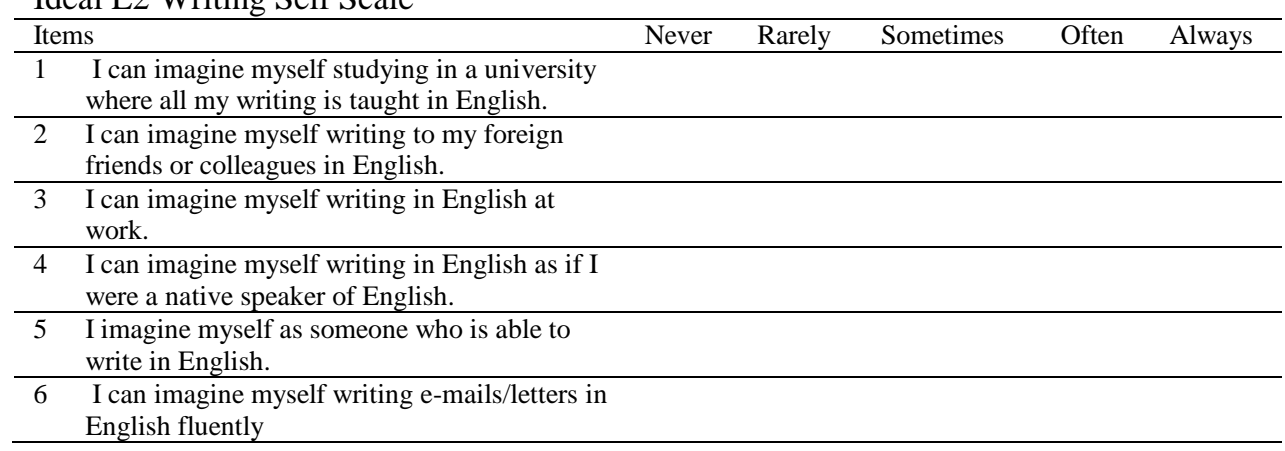

